\title{
PENGARUH NANOPARTIKEL PLGA Nigella sativa DALAM MENURUNKAN RADIKAL BEBAS MALONDIALDEHIDA HEPAR TIKUS MODEL DM TIPE 2
}

\author{
Ema Pristi Yunita* ${ }^{\star}$, Rizta Widya Pangestika*, Efta Triastuti*
}

\begin{abstract}
Abstrak
Diabetes melitus (DM) dengan glukosa darah yang tidak terkontrol dapat memicu pembentukan radikal bebas yaitu produk malondialdehida (MDA) di hepar. Radikal bebas tersebut dapat diturunkan menggunakan senyawa antioksidan (timokuinon). Timokuinon terkandung dalam biji Nigella sativa. Produk herbal sering mengalami kegagalan efikasi akibat rendahnya bioavailabilitas. Oleh karena itu, dilakukan terobosan baru yaitu formulasi ekstrak biji Nigella sativa dengan sistem penghantaran nanopartikel PLGA. Penelitian ini dillakukan untuk mengetahui pengaruh nanopartikel PLGA dalam memperbaiki efektivitas ekstrak biji jintan hitam dalam menurunkan produk radikal bebas berupa malondialdehida (MDA) di hepar tikus model DM tipe 2. Desain penelitian adalah true experimental posttest-only controlled design. Sebanyak 24 tikus yang diinduksi DM tipe 2 menggunakan streptozocin, kemudian dibagi menjadi empat kelompok yaitu kelompok yang diberi akuades dan pakan normal tanpa terapi $\left(\mathrm{P}_{\mathrm{n}}\right)$, glibenklamid $0,45 \mathrm{mg} / \mathrm{kgBB}\left(\mathrm{P}_{\mathrm{p}}\right)$, non-nanopartikel ekstrak biji Nigella sativa 48 $\mathrm{mg} / \mathrm{kgBB} / \mathrm{hari}\left(\mathrm{P}_{1}\right)$, dan nanopartikel PLGA ekstrak biji Nigella sativa $48 \mathrm{mg} / \mathrm{kgBB} / \mathrm{hari}\left(\mathrm{P}_{2}\right)$ selama 26 hari. Data dianalisis menggunakan uji hipotesis Kruskal Wallis. Untuk mengetahui kadar MDA digunakan metode asam tiobarbiturat. Rerata kadar MDA dari yang terendah adalah $P_{2}(0,3652 \pm 0,0363 \mathrm{ng} / \mathrm{mL}), P_{1}(0,3749 \pm 0,0242$ $\mathrm{ng} / \mathrm{mL}), P_{n}(0,4084 \pm 0,0719 \mathrm{ng} / \mathrm{mL})$, dan $P_{p}(0,4329 \pm 0,0588 \mathrm{ng} / \mathrm{mL})$. Terdapat perbedaan kadar MDA hepar tikus model DM tipe 2 yang tidak berbeda bermakna pada semua kelompok perlakuan (Kruskal Wallis, $p=0,199$ ). Hasil penelitian ini masih belum dapat menunjukkan kemampuan nanopartikel PLGA Nigella sativa dalam menurunkan radikal bebas MDA di hepar.
\end{abstract}

Kata kunci: malondialdehida hepar, nanopartikel PLGA, Nigella sativa.

\section{THE INFLUENCE OF Nigella sativa PLGA NANOPARTICLES IN REDUCING THE FREE RADICALS MALONDIALDEHYDE LIVER TYPE 2 DM RATS MODEL}

\begin{abstract}
Diabetes mellitus with uncontrolled blood glucose might trigger the formation of free radicals namely malondialdehyde (MDA) product in liver. The free radicals could be reduced using antioxidant compounds (thymoquinone). Thymoquinone contained in Nigella sativa seeds. Herbal products often fail efficacy due to low bioavailability. Therefore, made a new breakthrough that Nigella sativa seed extract formulation with PLGA nanoparticle delivery systems. This study was to determine the influence PLGA nanoparticles to improve the effectiveness of black cumin seed extract in reducing free radical products in the form of malondialdehyde (MDA) in liver rat model of type $2 \mathrm{DM}$. This study design was a true experimental posttest-only controlled design. Twenty four rats were divided into four groups that were induced type $2 \mathrm{DM}$ using streptozocin, then divided into four groups that were given distilled water and feed normally without treatment $\left(P_{n}\right), 0.45 \mathrm{mg} / \mathrm{kgBW}$ glibenclamide $\left(P_{p}\right), 48 \mathrm{mg} / \mathrm{kgBW} /$ day of non-nanoparticle Nigella sativa seed extract $\left(P_{1}\right)$, and $48 \mathrm{mg} / \mathrm{kgBW} /$ day of PLGA nanoparticles Nigella sativa seed extract $\left(P_{2}\right)$ for 26 days. Data were analyzed with Kruskal Wallis hypothesis test. The thiobarbituricacid method was used to determine MDA level. The mean of MDA level from the lowest were $P_{2}(0.3652 \pm 0.0363 \mathrm{ng} / \mathrm{mL}), P_{1}(0.3749 \pm 0.0242 \mathrm{ng} / \mathrm{mL}), P_{n}(0.4084 \pm 0.0719 \mathrm{ng} / \mathrm{mL})$, and $P_{p}$ $(0.4329 \pm 0.0588 \mathrm{ng} / \mathrm{mL})$. There were differences in the rat model of liver MDA levels type $2 \mathrm{DM}$ was not significantly different in all treatment groups (Kruskal Wallis, $p=0,199$ ). The results of this research still could not show the ability of Nigella sativa PLGA nanoparticles in reducing free radicals in the liver MDA.
\end{abstract}

Keywords: liver malondialdehyde, PLGA nanoparticles, Nigella sativa.

* Program Studi Farmasi, FKUB

E-mail: emapristi@gmail.com 


\section{Pendahuluan}

Diabetes melitus (DM) merupakan suatu penyakit metabolik. ${ }^{1}$ Penderita DM di Indonesia diperkirakan akan meningkat menjadi 14,1 juta pada tahun 2035. ${ }^{2}$ DM tipe 2 merupakan $90 \%$ dari kasus penderita diabetesdi dunia. ${ }^{3}$

Pada kondisi DM, peningkatanglukosa darah dapat mendorong pembentukan radikal bebas. Adanya radikal bebasdapat dikontrololehantioksidan. ${ }^{4}$ Biji jintan hitam yang mengandung timokuinon terbukti memiliki aktivitas antioksidan kuat. ${ }^{5}$

Penelitian ini perlu dilakukan untuk mengetahui pengaruh pemberian nanopartikel PLGA dalam memperbaiki efektivitas ekstrak biji jintan hitam. Dengan demikian mampu meningkatkan efektivitas terapi ekstrak biji jintan hitam melalui penurunan produk radikal bebas berupa malondialdehida (MDA) di hepar tikus model DM tipe 2.

Tujuan dari penelitian ini adalah untuk mengetahui perbedaan kadar MDA hepar tikus model DM tipe 2 yang diberi nanopartikel PLGA ekstrak biji jintan hitam, nonnanopartikel ekstrak biji jintan hitam, kelompok yang tidak diberi terapi, dan kelompok yang diberi glibenklamid.

\section{Bahan dan Metode}

\section{Hewan Coba}

Hewan coba pada penelitian ini adalah tikus Sprague dawley jantan yang berusia 18 bulan dan memiliki berat badan 180-400 g. Induksi DM tipe 2 dilakukan dengan pemberian pakan Diet Tinggi Lemak (DTL) dan streptozocin (STZ) $35 \mathrm{mg} / \mathrm{kgBB}$. Pemberian terapi dilakukan selama 26 hari. Sebanyak 24 ekor tikus dibagi menjadi empat kelompok perlakuan secara acak, tiap kelompok berisi 6 ekor tikus. Kelompok kontrol negatif $\left(P_{n}\right)$ yaitu tikus yang diinduksi DM tipe 2 diberi akuades dan pakan normal tanpa terapi ekstrak biji jintan hitam.Kelompok kontrol positif $\left(P_{p}\right)$ yaitu tikus yang diinduksi DM tipe 2 diberi terapi glibenklamid dosis $0,45 \mathrm{mg} / \mathrm{kgBB}$.Kelompok perlakuan $\left(\mathrm{P}_{1}\right)$ yaitu tikus yang diinduksi DM tipe 2 diberi non-nanopartikel ekstrak biji jintan hitam dosis $48 \mathrm{mg} / \mathrm{kgBB} / \mathrm{hari}$. Kelompok perlakuan $\left(\mathrm{P}_{2}\right)$ yaitu tikus yang diinduksi DM tipe 2 diberi nanopartikel PLGA ekstrak biji jintan hitam dosis $48 \mathrm{mg} / \mathrm{kgBB} / \mathrm{hari}$.

\section{Desain Penelitian}

Penelitan ini menggunakan desain true experimental dengan metode posttest-only controlled design. Prosedur dalam penelitian ini telah mendapatkan persetujuan dari Komisi Etik Penelitian Kesehatan Fakultas Kedokteran Universitas Brawijaya.

\section{Ekstraksi Biji Jintan Hitam}

Serbuk biji jintan hitam sebanyak $150 \mathrm{~g}$ diekstraksi dengan etanol $95 \% 900 \mathrm{~mL}$ menggunakan alat extraction unit E-816. Ekstraksi soxhlet dilakukan selama 3 jam. Ekstrak dipisahkan dari pelarutnya dengan dievaporasi pada suhu $60^{\circ} \mathrm{C}$ menggunakan water bath rotary evaporator sampai terbentuk ekstrak semisolid.

\section{Identifikasi Timokuinon dengan Kromatografi Lapis Tipis (KLT)}

Plat KLT silika gel disiapkan dengan ukuran $20 \times 4 \mathrm{~cm}$. Diukur eluen yang terdiri dari n-heksan : etil asetat $=9: 1$ (12). Ditotolkan $2 \mu \mathrm{L}$ ekstrak biji jintan hitam dan 2 $\mu \mathrm{L}$ standar timokuinon pada plat KLT. Diamati noda pada Lampu UV dengan panjang gelombang $254 \mathrm{~nm}$.

\section{Pembuatan Diet Tinggi Lemak (DTL)}

Diet ini diberikan selama 40 hari dengan ketentuan jumlah makanan rata-rata $25 \mathrm{~g} / \mathrm{hari}$ untuk setiap tikus. Sebanyak $25 \mathrm{~g}$ DTL mengandungkonsentrat PARS 50\%, tepung terigu $25 \%$, kolesterol $1 \%$, asam kolat $0,1 \%$, dan minyak babi $2,5 \%{ }^{6}$

\section{Pembuatan Nanopartikel PLGA}

Ekstrak biji jintan hitam ditimbang 3,456 mg dengan neraca analitis. PLGA ditimbang $17,28 \mathrm{~g}$ dengan neraca analitis. Propylene carbonate (PC) diukur 1036,8 mL dengan gelas ukur. Ekstrak biji jintan hitam dan PLGA dilarutkan dalam PC menggunakan magnetic stirrer 500 rpm selama 30 menit sampai tercampur. Pluronic F68 ditimbang 69,12 g dengan neraca analitis. Aquabidestilata diukur 6,912 L dengan gelas ukur. Pluronic F68 dilarutkan dalam aquabidestilata menggunakan magnetic stirrer $1250 \mathrm{rpm}$ selama 30 menit hingga larut. Campuran ekstrak, PLGA, dan PC dipipet kemudian ditambahkan ke dalam campuran Pluronic F68 
dan aquabidestilata dengan laju $0,5 \mathrm{~mL} /$ menit. Campuran tersebut disentrifugasi $10000 \mathrm{~g} \mathrm{~T}=$ $4^{\circ} \mathrm{C}$ selama 30 menit. Pellet yang terbentuk dipisahkan dan ditimbang menggunakan neraca analitis. ${ }^{7}$

\section{Karakterisasi Morfologi Nanopartikel PLGA}

Pellet nanopartikel dipipet lalu diletakkan pada carbon tip. Diberi etanol absolut agar cairan cepat menguap. Pellet nanopartikel dikonduktifkan lalu diamati ukuran nanopartikel pada Scanning Electron Microscope (SEM) merek FEl tipe inspect $\mathrm{S} 50$ pada perbesaran 20.000x, dan 50.000x.

\section{Pemeriksaan Kadar Glukosa Darah Puasa (GDP)}

Sebelum dilakukan pengukuran kadar GDP, tikus dipuasakan selama 10-12 jam. Dilakukan pemeriksaan kadar GDP sebelum perlakuan, satu kali setelah 40 hari DTL, tiga hari setelah diinduksi STZ, dan satu kali setelah 26 hari diberikan terapi.

\section{Pengukuran Kadar MDA Hepar}

Organ hepar dibersihkan dan dicuci dengan phosphate buffer saline (PBS) hingga bersih. Diambil sebanyak $110 \mathrm{mg}$ dan dicuci dengan PBS. Dihancurkan dengan batang penumbuk lalu homogenat ditambah $1 \mathrm{~mL}$ PBS. Dilakukan sentrifugasi pada kecepatan 2800 rpm selama 7 menit pada suhu $4^{\circ} \mathrm{C}$. Sebanyak $0,5 \mathrm{~mL}$ supernatan dipindahkan pada mikrotube baru. Sebanyak $0,2 \mathrm{~mL}$ supernatan dipindahkan pada falkon baru, ditambahkan dengan $0,05 \mathrm{~mL} \mathrm{NaOH} 3 \mathrm{M}$, dilakukan vortex, dan diinkubasi pada suhu $60^{\circ} \mathrm{C}$ selama 30 menit. Ditambahkan $2 \mathrm{~mL}$ $\mathrm{H}_{2} \mathrm{SO}_{4} \quad 0,05 \mathrm{M}$ dan $1 \mathrm{~mL}$ larutan TCA $(20 \%$ $\mathrm{b} / \mathrm{v})$, dilakukan vorteks, disentrifugasi dengan kecepatan $3000 \mathrm{rpm}$ pada suhu $4^{\circ} \mathrm{C}$ selama 10 menit. Sebanyak $2 \mathrm{~mL}$ supernatan dipindahkan ke falkon baru, ditambahkan $1 \mathrm{~mL}$ larutan TBA (thiobarbituric acid) $(0,355 \% \mathrm{~b} / \mathrm{v})$, dilakukan vortex, dan diinkubasi pada suhu $90^{\circ} \mathrm{C}$ selama 40 menit. Dilakukan sentrifugasi dengan kecepatan $3000 \mathrm{rpm}$ pada suhu $4^{\circ} \mathrm{C}$ selama 10 menit.Setelah dingin pada suhu ruang, konsentrasinya diukur dengan spektrofotometer UV-Vis pada panjang gelombang maksimum yaitu $532 \mathrm{~nm} .{ }^{8}$

\section{Hasil}

Ekstraksi dan Uji Fitokimia Kualitatif Ekstrak Biji Jintan Hitam

Hasil ekstraksi didapatkan ekstrak cair biji jintan hitam berwarna coklat kehitaman sebanyak $75,3 \mathrm{~g}(50,2 \%)$. Warna ekstrak biji jintan hitam yang diperoleh telah sesuai dengan literatur yaitu berwarna coklat kehitaman.

\section{Identifikasi Timokuinon Ekstrak Biji Jintan Hitam}

Hasil identifikasi menunjukkan bahwa ekstrak biji jintan hitam dan standar timokuinon memiliki noda pada plat KLT dengan nilai Rf yang sama yaitu 0,765 . Dari hasil identifikasi ini menunjukkan bahwa ekstrak biji jintan hitam positif mengandung timokuinon.

\section{Nanopartikel PLGA Ekstrak Biji Jintan Hitam}

Total pellet yang diperoleh untuk terapi selama 26 hari adalah $4,09 \mathrm{~g}$. Pellet yang diperoleh memiliki warna putih keruh.

\section{Karakterisasi Morfologi Nanopartikel PLGA Ekstrak Biji Jintan Hitam}

Hasil uji SEM pada Tabel 2 menunjukkan bahwa sediaan nanopartikel yang dibuat memiliki ukuran partikel yang berukuran nanometer. Hasil pembuatan sediaan nanopartikel PLGA ekstrak biji jintan hitam memiliki diameter terendah 50,14 nm; diameter tertinggi $93,98 \mathrm{~nm}$; dan rerata diameter yaitu $68,80 \mathrm{~nm}$. Dari hasil uji SEM dapat dilihat bahwa terdapat permukaan partikel yang halus dan kasar serta partikel tidak berbentuk. 
Tabel 1. Hasil uji fitokimia kualitatif

\begin{tabular}{|c|c|c|c|}
\hline $\begin{array}{l}\text { Jenis Uji } \\
\text { Fitokimia }\end{array}$ & Pereaksi & Hasil & Keterangan \\
\hline $\begin{array}{l}\text { Minyak } \\
\text { atsiri }\end{array}$ & Sudan III & Terbentuk warna merah tua & + \\
\hline \multirow[t]{3}{*}{ Alkaloid } & Mayer & Tidak terbentuk endapan putih atau krim & - \\
\hline & Wagner & Terbentuk endapan coklat kemerahan & + \\
\hline & Dragendroff & Tidak terbentuk endapan kuning atau jingga & - \\
\hline Saponin & - & $\begin{array}{l}\text { Terbentuk buih yang stabil selama } 10 \text { menit dengan tinggi } \\
1 \mathrm{~cm} \text {, dan terbentuk emulsi setelah penambahan minyak } \\
\text { zaitun }\end{array}$ & + \\
\hline \multirow{3}{*}{ Flavonoid } & Amonia encer dan $\mathrm{H}_{2} \mathrm{SO}_{4}$ & Terbentuk warna kuning & + \\
\hline & $\begin{array}{l}1 \% \text { larutan aluminium } \\
\text { (Al) }\end{array}$ & Terbentuk warna kuning & + \\
\hline & $\begin{array}{l}\text { Etil asetat dan ammonia } \\
\text { encer }\end{array}$ & Terbentuk warna kuning & + \\
\hline \multirow[t]{3}{*}{ Tanin } & $\begin{array}{l}\text { Larutan } \mathrm{NaCl} 0,9 \% \\
\text { panas dan } \mathrm{FeCl}_{3}\end{array}$ & $\begin{array}{l}\text { Terbentuk endapan berwarna biru, biru kehitaman, } \\
\text { hijau, atau biru kehijauan }\end{array}$ & + \\
\hline & $\begin{array}{l}1 \% \text { larutan gelatin dan } \\
\mathrm{FeCl}_{3}\end{array}$ & $\begin{array}{l}\text { Terbentuk endapan berwarna biru, biru kehitaman, } \\
\text { hijau, atau biru kehijauan }\end{array}$ & + \\
\hline & Gelatin- $\mathrm{NaCl}$ dan $\mathrm{FeCl}_{3}$ & $\begin{array}{l}\text { Terbentuk endapan berwarna biru, biru kehitaman, } \\
\text { hijau, atau biru kehijauan }\end{array}$ & + \\
\hline Terpenoid & $\begin{array}{l}\text { Kloroform dan } \mathrm{H}_{2} \mathrm{SO}_{4} \\
\text { pekat }\end{array}$ & Terbentuk warna coklat kemerahan pada permukaan & + \\
\hline
\end{tabular}

Keterangan:

$(+)=$ positif mengandung zat yang diuji

$(-)=$ negatif/tidak mengandung zat yang diuji

Tabel 2. Hasil uji SEM sediaan nanopartikel

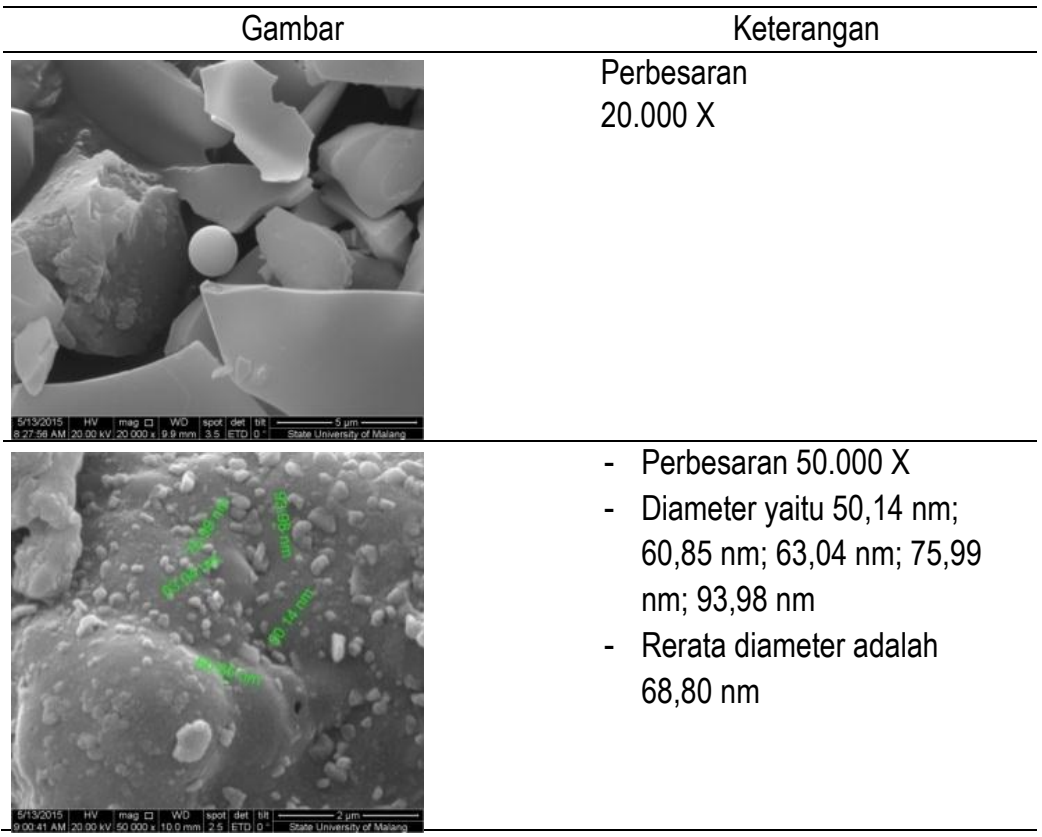

\section{Induksi DM Tipe 2}

Induksi DM tipe 2 pada penelitian ini menggunakan pakan DTL dan STZ dosis rendah yaitu $35 \mathrm{mg} / \mathrm{kgBB}$.Apabila dilihat dari hasil GDP setelah 40 hari pemberian pakan
DTL, didapatkan 21 tikus mengalami peningkatan GDP. Setelah pemberian STZ dosis $35 \mathrm{mg} / \mathrm{kgBB}$, gejala-gejala fisiologis yang terjadi pada tikus meliputi poliuri (ditandai dengan sekam basah), polidipsi (ditandai 
Yunita EP,et al.

dengan air minum yang diberikan setiap hari habis), dan polifagi (ditandai tidak terdapat sisa pakan). Semua tikus mengalami peningkatan kadar GDP dan dinyatakan DM karena kadar GDP telah melebihi $126 \mathrm{mg} / \mathrm{dL} .{ }^{14}$

\section{Kadar MDA Hepar}

Rerata kadar MDA hepar dapat dilihat pada Tabel 3. Dari hasil rerata kadar MDA hepar tikus, kelompok $P_{2}$ dan kelompok $P_{1}$ menunjukkan kadar MDA yang rendah yaitu 0,3652 $\pm 0,0363 \mathrm{ng} / \mathrm{mL}$ dan 0,3749 $\pm 0,0242$ $\mathrm{ng} / \mathrm{mL}$ jika dibandingkan kontrol negatif yaitu $0,4084 \pm 0,0719 \mathrm{ng} / \mathrm{mL}$. Dari semua kelompok, $\mathrm{P}_{2}$ adalah kelompok dengan kadar MDA hepar terendah. Sebaliknya, kelompok $P_{p}$
Pengaruh Nanopartikel PLGA Nigella sativa memiliki kadarMDA hepar tertinggi yaitu 0,4329 $\pm 0,0588 \mathrm{ng} / \mathrm{mL}$.

Apabila dibandingkan dengan kelompok $P_{n}$, kelompok $P_{2}$ mengalami penurunan kadar MDA hepar sebesar 10,58\%, diikuti oleh kelompok $P_{1}$ yang mengalami penurunan kadar MDA hepar sebesar 8,20\%. Sementara pada kelompok $P_{p}$ mengalami peningkatan kadar MDA hepar sebesar 6,00\%.

Untuk mengetahui adanya perbedaan antar kelompok perlakuan, maka dilakukan uji Kruskal Wallis dengan hasil $p=0,199$ ( $p>$ 0,05). Hasil ini menunjukkan bahwa tidak terdapat perbedaan kadar MDA hepar yang signifikan secara statistik antara keempat kelompok perlakuan.

Tabel 3. Kadar MDA hepar tikus DM tipe 2

\begin{tabular}{lccc}
\hline Perlakuan & $\mathrm{N}$ & $\begin{array}{c}\text { Rerata Kadar MDA Hepar } \pm \text { SD } \\
(\mathrm{ng} / \mathrm{mL})\end{array}$ & $\begin{array}{c}\text { Median } \\
(\text { Min-Maks })(\mathrm{ng} / \mathrm{mL})\end{array}$ \\
\hline Kontrol Negatif $\left(\mathrm{P}_{\mathrm{n}}\right)$ & 6 & $0,4084 \pm 0,0719$ & $0,4075(0,3282-0,4868)$ \\
Kontrol Positif $\left(\mathrm{P}_{\mathrm{p}}\right)$ & 5 & $0,4329 \pm 0,0588$ & $0,4128(0,3652-0,5132)$ \\
Perlakuan 1 $\left(\mathrm{P}_{1}\right)$ & 6 & $0,3749 \pm 0,0242$ & $0,3732(0,3494-0,4022)$ \\
Perlakuan 2 $\left(\mathrm{P}_{2}\right)$ & 6 & $0,3652 \pm 0,0363$ & $0,3626(0,3282-0,4075)$ \\
\hline
\end{tabular}

\section{Pembahasan}

\section{Ekstraksi dan Uji Fitokimia Kualitatif Ekstrak Biji Jintan Hitam}

Hasil ekstraksi yang diperoleh pada penelitian ini berbeda dengan jurnal rujukan. Pada jurnal rujukan yang menggunakan metode ekstraksi soxhlet dan perbandingan pelarut yang sama, diperoleh ekstrak semisolid sebanyak 22,78\%, dan proses ekstraksi dilakukan selama 3 jam sedangkan jurnal rujukan menggunakan waktu selama 30 menit. ${ }^{9}$ Sehingga diperoleh ekstrak yang lebih banyak dan memiliki konsistensi cair Dari hasil uji fitokimia kualitatif (lihat Tabel 1) diketahui ekstrak biji jintan hitam positif mengandung minyak atsiri, saponin, flavonoid, tanin, dan terpenoid yang sesuai dengan literatur. $9,11 \mathrm{Hal}$ ini menunjukkan bahwa proses ekstraksi dengan metode soxhlet dan pelarut etanol dapat menarik senyawa-senyawa yang terkandung dalam biji jintan hitam terutama minyak atsiri. Namun, pada hasil uji alkaloid menunjukkan hasil negatif dan kurang sesuai dengan literatur.

\section{Identifikasi Timokuinon Ekstrak Biji Jintan} Hitam

Hasil penelitian menunjukkan bahwa ekstrak biji jintan hitam positif mengandung timokuinon dengan nilai Rf pada plat KLT yaitu 0,765 . Pada penelitian lain didapatkan nilai Rf timokuinon $0,048 \pm 0,040$ dan $0,820 .{ }^{12,13}$ Adanya perbedaan nilai $\mathrm{Rf}$ ini dapat diakibatkan oleh penggunaan pelarut ekstrak yang berbeda sehingga zat aktif timokuinon yang dapat terekstraksi pun juga berbeda. Penggunaan eluen dan metode yang berbeda juga berpengaruh dalam proses eluasi zat aktif timokuinon yang terkandung pada ekstrak maupun timokuinon standar.

\section{Karakterisasi Morfologi Nanopartikel PLGA Ekstrak Biji Jintan Hitam}

Hasil pembuatan nanopartikel PLGA ekstrak biji jintan hitam pada penelitian ini tidak sejalan dengan penelitian oleh Slutter et al (2010), yang menunjukkan bahwa nanopartikel PLGA yang dibuat dengan metode penguapan pelarut memiliki permukaan yang halus dan partikel berbentuk sferis. ${ }^{15}$ Bentuk tidak seragam seperti yang terlihat pada penelitian ini dapat dipengaruhi oleh banyak faktor antara lain peningkatan jumlah polimer PLGA sehingga terbentuk partikel tidak sferis, adanya 
polimer yang mengalami aglomerasi dan tidak berbentuk, serta peningkatan ukuran partikel; peningkatan jumlah ekstrak yang menyebabkan rata-rata diameter dan distribusi granul menjadi lebih besar; makin tingginya konsentrasi stabilizer yang digunakan sehingga mengurangi ukuran partikel dari nanopartikel yang dihasilkan; serta peningkatan waktu sonikasi yang menurunkan ukuran diameter partikel. ${ }^{16}$

\section{Induksi DM Tipe 2}

Pemberian pakan DTL pada penelitian ini bertujuan untuk menghasilkan kondisi resistensi insulin sedangkan injeksi STZ bertujuan untuk menghasilkan kerusakan sel $\beta$ pankreas secara parsial sehingga akan menggangu dalam proses sekresi insulin. ${ }^{17}$ Setelah 40 hari pemberian pakan DTL, terjadi peningkatan berat badan yang cukup tinggi pada semua kelompok. Peningkatan berat badan ini disebabkan karena konsumsi makanan yang kaya energi dalam bentuk lemak jenuh dan akan terdeposisi dalam berbagai bantalan lemak tubuh. Pemberian pakan DTL dapat mengakibatkan kadar trigliserida meningkat yang merupakan sumber peningkatan ketersediaan asam lemak. Penggunaan asam lemak dapat mengganggu efek hambatan hormon insulin terhadap produksi glukosa di hepar dan mengurangi pengambilan glukosa oleh otot rangka. ${ }^{17} \mathrm{Hal}$ ini yang menyebabkan terjadinya peningkatan GDP pada hewan coba. Seluruh tikus dalam penelitian ini telah dinyatakan DM karena STZ masuk ke dalam sel $\beta$ pankreas melalui pengangkut glukosa GLUT2 yang selanjutnya mengakibatkan perubahan pada DNA sel $\beta$ pankreas sehingga terjadi penghambatan dalam sintesis dan sekresi insulin. ${ }^{18}$

\section{Kadar MDA Hepar}

Dari rerata hasil pengukuran kadar MDA hepar, kelompok $\mathrm{P}_{2}$ memiliki nilai yang paling rendah. Hal ini dapat diduga nanopartikel PLGA termetabolisme dengan baik dalam hepar sehingga timokuinon memberikan efek lebih maksimal sebagai antioksidan untuk menurunkan kadar MDA pada hepar.Hal ini diperkuat oleh penelitian yang menunjukkan bahwa hasil autoradiografi seluruh tubuh dan eksperimen distribusi kuantitatif pada tikus menunjukkan bahwa beberapan formulasi dari PLGA seperti nanopartikel akan terakumulasi cepat salah satunya pada organ hepar. ${ }^{19}$ Hasil penelitian tentang evaluasi besarnya distribusi dan retensi jaringan setelah pemberian nanopartikel PLGA secara oral selama 7 hari pada mencit menunjukkan bahwa persentase rata-rata partikel yang terlokalisasi tertinggi terdapat pada hepar $(40,04 \%) .^{20}$

Pada kelompok $\mathrm{P}_{1}$ menunjukkan bahwa ekstrak biji jintan hitam dapat menurunkan kadar MDA hepar apabila dibandingkan dengan kontrol negatif. Hal ini menunjukkan bahwa ekstrak biji jintan hitam dapat memberikan efek dalam menurunkan peroksidasi lipid pada hepar walaupun lebih rendah kemampuannya jika dibandingkan ekstrak yang dibuat sebagai sediaan nanopartikel. Efek penurunan peroksidasi lipid ini diduga merupakan aktivitas antioksidan dari timokuinon dalam ekstrak biji jintan hitam. Aktivitas antioksidan minyak biji jintan hitam yang terutama mengandung timokuinon bekerja dengan menghambat peroksidasi dan penangkapan radikal. ${ }^{21} \mathrm{MDA}$ merupakan hasil dari peroksidasi lipid sehingga zat aktif berupa timokuinon yang terdapat dalam ekstrak biji jintan hitam harus memiliki sifat lipofilik untuk dapat bekerja secara optimal dalam menurunkan MDA. Timokuinon merupakan antioksidan larut lemak sehingga mampu melewati membran lapisan lemak dan menurunkan pembentukan ROS (Reactive Oxygen Species) di mitokondria.

\section{Kesimpulan}

Dapat disimpulkan dari penelitian ini bahwa terdapat perbedaan kadar MDA hepar tikus model DM tipe 2, tetapi tidak signifikan secara statistik pada kelompok yang diberi nanopartikel PLGA ekstrak biji jintan hitam, non-nanopartikel ekstrak biji jintan hitam, kelompok yang tidak diberi terapi, dan kelompok yang diberi glibenklamid.Kadar MDA hepar pada kelompok yang diberi nanopartikel PLGA ekstrak biji jintan hitam menghasilkan penurunan kadar MDA hepar yang paling besar dibandingkan dengan kelompok perlakuan yang lain. 


\section{Saran}

Dari hasil ini dapat disarankan pemberian biji jintan hitam sebagai terapi tambahan pada pasien DM tipe 2. Selain itu, diperlukan pengukuran kadar HOMA-IR dan HOMA- $\beta$ untuk mengetahui apakah model hewan coba telah mengalami kondisi resistensi insulin pada penelitian serupa.

\section{Daftar Pustaka}

1. American Diabetes Association.. Standards of Medical Care in Diabetes2014. Diabetes Care. 2014; 37(1):14-90.

2. International Diabetes Federation.. IDF Diabetes Atlas. $6^{\text {th }}$ edition. Brussels: International Diabetes Federation. 2013.

3. (WHO) World Health Organization.Diabetes.(Online).2013.http:/ /www.who.int/mediacentre/factshees/ fs312/en/. Diakses 17 September 2014.

4. Winarsi H.Antioksidan Alami dan Radikal Bebas, Potensi dan Aplikasinya dalam Kesehatan. Yogyakarta: Kanisius. 2007. HIm 21-24.

5. Alimohammadi $\mathrm{S}$, Hobbenaghi R, Javanbakht J, Kheradmand D, Mortezaee $\mathrm{R}$, Tavakoli $\mathrm{M}$, et al. Protective and Antidiabetic Effects of Extract from Nigella sativa on Blood Glucose Concentrations Against Streptozotocin (STZ)-Induced Diabetic in Rats: An Experimental Study with Histopathological Evaluation. Diagnostic Pathology. 2013;8(137):1-7.

6. Pranata FJ. Pengaruh Pemberian Ekstrak Daun Pare terhadap Kadar Insulin pada Tikus Puth Strain Wistar Model Diabetes Mellitus Tipe 2 dengan Hiperinsulinemia. Tugas Akhir. Tidak Diterbitkan. Malang: Universitas Brawijaya. 2010.

7. Paul S, Bhattacharyya SS, Boujedaini N, Khuda-Bukhsh AR. Anticancer Potentials of Root Extract of Polygala senega and Its PLGA Nanoparticles-encapsulated Form. Evidence-Based Complementary and Alternative Medicine. 2011; 1-13.

8. Moselhy HF, Reid RG, Yousef $S$, and Boyle S. A Specific, Accurate and Sensitive Measure of Total Plasma
Malondialdehyde by HPLC. Journal of Lipid Research. 2013; 54(3): 852-858.

9. Dwarampudi LP, Palaniswamy D, Nithyanantham $M$, and Raghu PS. Antipsoriatic Activity and Cytotoxicity of Ethanolic Extract of Nigella sativa Seeds. Pharmacognosy Magazine. 2012; 8(32): 268-272.

10. Bashir MU and Qureshi HJ. Analgesic Effect of Nigella sativaSeeds Extract on Experimentally Induced Pain in Albino Mice. Journal of the College of Physicians and Surgeons Pakistan. 2010; 20(7): 64467.

11. Tembhurne SV, Feroz S, More BH, and Sakarkar DM. A Review on Therapeutic Potential ofNigella sativa (Kalonji) Seeds. Journal of Medicinal Plants Research. 2014; 8(3):167-177.

12. Suthar MP, Patel PN, Shah TG, and Patel RK. In Vitro Screening ofNigella sativa Seeds for Antifungal Activity. International Journal of Pharmaceutical and Applied Sciences. 2010; 1(2): 4-91.

13. Alam $P$, Yusufoglu $H$, and Alam $A$. HPTLC Densitometric Method for Analysis of Thymoquinone inNigella sativa Extracts and Marketed Formulations. Asian Pacific Journal of Tropical Disease. 2013;3(6):467-471.

14. Jung JY, Lim Y, Moon MS, Kim JY, and Kwon O. Onion Peel Extracts Ameliorate Hyperglycemia and Insulin Resistance in High Fat Diet/Streptozotocin-Induced Diabetic Rats. Nutrition \& Metabolism. 2011; 8(18):1-8.

15. Slutter B, Bal S, Keijer C, Mallants R, Hagenaars N, Que I, et al. Nasal Vaccination with $\mathrm{N}$-Trimethyl Chitosan and PLGA based Nanoparticles: Nanoparticle Characteristics Determine Quality and Strength of the Antibody Response in Mice against the Encapsulated Antigen. Vaccine. 2010; 28(38):6282-6291.

16. Mainardes RM and Evangelista RC. PLGA Nanoparticles Containing Praziquantel: Effect of Formulation 
Variables on Size Distribution. International Journal of Pharmaceutics. 2005; 290(1-2):137-144.

17. Srinivasan K, Viswanad B, Asrat L, Kaul CL, Ramarao P. Combination of High-Fat Diet-Fed and Low-Dose StreptozotocinTretaed Rat: A Model For Type 2 Diabetes and Pharmacological Screening. Pharmacological Research. 2005; 52(4):313-320.

18. Szkudelski T. The Mechanism of Alloxan and Streptozotocin Action in B Cells of the Rat Pancreas. Physiological Research. 2001; 50(6):537-546.

19. Makadia HK and Siegel SJ. Poly Lacticco-glycolic Acid (PLGA) as Biodegradable Controlled Drug Delivery Carrier. Polymer. 2011;3(3):1377-1397.

20. Semete B, Booysen L, Lemmer $Y$, Kalombo L, Katata L, Verschoor J, et al. In Vivo Evaluation of The Biodistribution and Safety of PLGA Nanoparticles as Drug Delivery Systems. Nanomedicine. 2010; 6(5):622-671.

21. Singh S, Das SS, Singh G, Schuff $C$, Lampasona MP, and Catalan CAN. Composition, in Vitro Antioxidant and Antimicrobial Activities of Essential Oil and Oleoresins Obtained from Black Cumin Seeds (Nigella sativa L.). Hindawi Publishing Corporation BioMed Research International. 2014; 1-10. 